\title{
Circulating Microparticles as a Predictor of Vascular Properties in Patients on Mechanical Circulatory Support; Hype or Hope?
}

\author{
P. IVAK ${ }^{1,3}$, J. PITHA ${ }^{4}$, I. NETUKA ${ }^{1,2}$ \\ All authors contributed equally to the manuscript preparation
}

${ }^{1}$ Department of Cardiovascular Surgery, Institute for Clinical and Experimental Medicine, Prague, Czech Republic, ${ }^{2}$ Second Department of Surgery, Department of Cardiovascular Surgery, First Faculty of Medicine, Charles University in Prague, Prague, Czech Republic, ${ }^{3} 3^{\text {rd }}$ Faculty of Medicine, Charles University, Prague, Czech Republic, ${ }^{4}$ Laboratory for Atherosclerosis Research, Institute for Clinical and Experimental Medicine, Prague, Czech Republic

Received November 1, 2015

Accepted March 11, 2016

On-line July 15, 2016

\begin{abstract}
Summary
Microparticles are small circulating vesicles originating from circulatory system and vascular wall cells released during their activation or damage. They possess different roles in regulation of endothelial function, inflammation, thrombosis, angiogenesis, and in general, cellular stress. Microparticles are the subject of intensive research in pulmonary hypertension, atherosclerotic disease, and heart failure. Another recently emerging role is the evaluation of the status of vasculature in end-stage heart failure patients treated with implantable ventricular assist devices. In patients implanted as destination therapy, assessment of the long-term effect of currently used continuous-flow left ventricular assist devices (LVADs) on vasculature might be of critical importance. However, unique continuous flow pattern generated by LVADs makes it difficult to assess reliably the vascular function with most currently used methods, based mainly on ultrasound detection of changes of arterial dilatation during pulsatile flow. In this respect, the measurement of circulating microparticles as a marker of vascular status may help to elucidate both short- and long-term effects of LVADs on the vascular system. Because data regarding this topic are very limited, this review is focused on the advantages and caveats of the circulating microparticles as markers of vascular function in patients on continuous-flow LVADs.
\end{abstract}

\section{Key words}

Microparticles • Ventricular assist device • Vascular function

\section{Corresponding author}

P. Ivak, Institute for Clinical and Experimental Medicine, Videnska 1958/9, 14021 Prague, Czech Republic. E-mail: peter.ivak@ikem.cz

\section{Introduction}

Left ventricular assist devices (LVADs) and heart transplantation are the leading therapeutic approaches to manage end-stage heart failure that is unresponsive to medical therapy (Kirklin et al. 2012). New developments in design of LVADs have facilitated their durability, effectiveness, and long-term reliability (Holman et al. 2013). The number of LVAD implantations for long-term destination therapy continues to increase each year as the acceptance of this therapy increases (Kirklin et al. 2014). Consequently, use of the latest generation of LVADs has had positive influence on overall patient survival rates (Rogers et al. 2010, Kirklin et al. 2013, Kirklin et al. 2014). Despite extensive experience in the management of patients with implanted LVADs, the occurrence of device-related complications and their prediction have become a new challenge in patients with long-term mechanical circulatory support therapy. Likewise, the assessment of vasculature and endothelium status by conventionally utilized methods, such as measurement of pulse wave velocity and 
endothelial dysfunction in peripheral vessels, is problematic because these devices generate non-pulsatile flow, thus making these methods much less reliable. Continuous blood flow is generally assumed to be nonphysiological and, therefore, may produce increased stress on endothelial and circulating cells. Pathophysiological mechanisms of this phenomenon and impact of continuous-flow LVADs on blood and endothelial cells remain unclear.

To delineate the effect of LVADs on the vasculature, newly detectable biomarkers related to cellular injury, stress, and apoptosis - microparticles have become an important focus of research.

Microparticles are complex vesicular structures that are anuclear fragments of cellular membrane and cytoplasmic material with a diameter of 0.1 to $1.0 \mu \mathrm{m}$. The plasma membrane surface of the microparticle contains phospholipids, and the microparticle itself encompasses proteins and cytoplasmic material from the cell of origin - both blood and endothelial cells (Burger and Touyz 2012). Microparticle formation encompasses loss of physiological phospholipid asymmetry of plasma membrane. Phosphatidylserine (PS) and phosphatidylethanolamine are usually located on the inside surface of plasmatic membrane, while phosphatidylcholine and sphingomyelin are present on outer surface of the membrane. Balance between these substances is sustained by enzymes flippase, floppase and scramblase (McGinn et al. 2016). Cell activation followed by increase of cytoplasmic calcium leads to dysregulation of these enzymes causing externalization of phosphatidylserine. Externalized PS can not only induce endothelial damage in inflammatory conditions (Amabile et al. 2013, Burger et al. 2012), but is also essential in initiating and propagating the coagulation at sites of vascular injury (Nomura et al. 2001, Sinauridze et al. 2007, Zhou et al. 2010).

Considered as the end-product of apoptosis and injury of different cell types, especially platelets, leukocytes, erythrocytes, and endothelial cells, circulating microparticles can act as a strong dysregulators of endothelial function (Dignat-George and Boulanger 2010). Shedding of microparticles is process that can also occur independently of apoptosis (Sapet et al. 2006). Microparticle release is stimulated by both physiological and pathological stimuli linked to cell activation, for example in platelets and endothelial cells shear stress represents such stimulus (Mc Ginn et al. 2106). Therefore, on one hand, the production of microparticles is believed to be a part of physiologic cell function, but on the other hand, significant increase of microparticles was described in several pathological conditions. Regarding the latter, elevated levels of microparticles correlate with cardiovascular diseases such as atherosclerotic disease (Van Wijk et al. 2003, Burnier et al. 2009), including coronary artery disease (Bernal Mizrachi et al. 2003, Bernal Mizrachi et al. 2004, Singh et al. 2012), carotid artery disease (Schiro et al. 2014), or stroke (Williams et al. 2007). Raise of microparticle concentrations is also associated with hypertension (Preston et al. 2003), atrial fibrillation (Ederhy et al. 2007) or pulmonary hypertension (Diehl et al. 2011). Increased levels microparticles were further found in metabolic diseases such as obesity, diabetes (Sabatier et al. 2002, Tramontano et al. 2010, França et al. 2015), and dyslipidemia (Boulanger et al. 2006). Furthermore, elevated microparticles could be strong predictor for complications in pregnancy, namely in the case of life threatening preeclampsia (Van Wijk et al. 2002, Bretelle et al. 2003, Gonzales-Quinteiro et al. 2004), but also in septic shock in general population of patients (Zafrani et al. 2013, Zhang et al. 2016). In addition, levels of circulating microparticles are also affected by various drug therapies, which may also play role in their use as a diagnostic tool. Reduction of microparticle levels was observed in patients treated by aspirin, calcium channel blockers or statins (McGinn et al. 2016).

In general, plasma microparticles are increased in most cardiovascular diseases, probably reflecting activation or damage of circulating cells or cells of the vasculature itself (Piccin et al. 2007) and this increase might be associated with increased risk of major cardiovascular clinical complications (Bernal Mizrachi et al. 2004). Microparticles may also act as an independent predictor of cardiovascular diseases (Amabile et al. 2014). Thereby, according to recent scientific literature, microparticles have potential to become diagnostic tool not only in cardiovascular diseases, but also in other pathological states associated with coagulation, endothelial dysfunction and metabolic or infectious diseases, and also complications in pregnancy. However, because of great complexity and variability regarding the origin and structure of microparticles, particular methods used for their determination could be of extreme importance.

Currently there are several methods used to detect microparticles; the two leading methods are flow cytometry and enzyme-linked immunosorbent assay 
(ELISA). A key advantage of flow cytometry is its specificity to surface antigens, which allows identification of the maternal cells and, therefore, by this method it is possible to assess the origin of the microparticles. The analysis of plasma samples clearly detects and differentiates microparticles of endothelial, platelet, leukocyte, and erythrocyte origins (Jy et al. 2004, Lacroix et al. 2010). The greatest advantages of the other technique, ELISA, are its high sensitivity and low cost. This methodology is based on measurement of concentration of phosphatidylserine, and aminophospholipids typically found on the inner surface of the plasmatic membrane, which is externalized by creation of macrovesicles, by outward blebbing of the membrane (Burger et al. 2013, Shah and Kontos 2014). However, the advantages are counterbalanced by the lower specificity of the method (Piccin et al. 2007, Jy et al. 2004).

Particular assay used for microparticle detection also determines which types of microparticles are detected and measured (Amiral and Seghatchian 2015). Results could be influenced by capture ligand selected, especially in flow cytometry. Previously published studies suggest that capture-based assays such as ELISA method correlate better with disease evolution and severity than flow cytometry (Connor et al. 2009, Owen et al. 2011, Aleman et al. 2011, Amiral and Seghatchian 2015). Design of capture-based assays has also great influence on nature and size of measured microparticles. Flow cytometry assays detect usually microparticles of size over $0.4 \mu \mathrm{m}$ (Amiral and Seghatchian 2015). However, main advantage of flow cytometry could be its ability to define the cell origin of circulating microparticles more precisely. Such approach is very important, because levels of microparticles of different cell origin are elevated in different pathological states. Platelet microparticle levels increase in states related to bleeding and thrombotic disorders, such as heparininduced thrombocytopenia (Warkentin et al. 1994, Hughes et al. 2000). In contrast, the increase of endothelial microparticles has been observed to correlate with loss of flow - mediated dilatation and arterial stiffness (Viera et al. 2012) and endothelial dysfunction (Bruyndonckx et al. 2014, McGinn et al. 2016) as well as with hyperlipidemia (Boulanger et al. 2006). Elevations of both platelet and endothelial microparticles were observed in thrombotic diseases, such as venous thromboembolism, antiphospholipid syndrome or thrombotic thrombocytopenic purpura (Burnier et al.
2009). This pattern of changes is also frequently found in hypertension and atherosclerotic disease including acute coronary syndromes (Burnier et al. 2009), but also in sepsis (Zhang et al. 2016). Nevertheless, it should be mentioned that microparticles are also released from other cell types. Leukocyte derived microparticles play role in pathophysiology of cardiovascular diseases (monocytes) and infectious diseases (HIV - lymphocytes). Erythrocyte derived microparticles are elevated in various clinical situations, particularly in those characterized by hemolysis (Rubin et al. 2012). In general, proportions of types of circulating levels of microparticles may differ between various diseases and it could be advantageous to assess not only total levels of circulating microparticles, but also to determine their cellular origin.

Taking all presented observations into account, assessment and especially interpretation of microparticle levels has become a complex issue, which could be particularly interesting to study in unique population of patients with end-stage heart failure, treated with LVADs.

\section{Recent knowledge about microparticles and ventricular assist devices}

The role of left ventricular assist devices (LVADs) is rapidly growing beyond the original role of bridging the patient to heart transplantation. The devices have become an alternate permanent therapy known as the destination therapy, which poses the question as to how these devices impact long-term properties of blood components and vessels.

Circulating cells are not only impacted by a milieu of non-pulsatile blood flow but also by the device itself. Mechanical stress produced by the rotary pump can cause possible ongoing disruption of cellular integrity. Therefore, circulating microparticles, as products of cellular damage, apoptosis, and stress, have recently attracted considerable research interest as an important biomarker tool or even a harbinger of cardiovascular adverse events. Table 1 summarizes current knowledge on this subject.

\section{Microparticles as predictor of adverse events in LVAD patients}

Aim of the first study of microparticles in patients with implanted LVADs was to establish microparticles as surrogate markers for platelet, 
Table 1. Studies analyzing an effect of LVADs on presence and profile of microparticles.

\begin{tabular}{|c|c|c|c|c|c|}
\hline $\begin{array}{l}\text { Author, } \\
\text { Date, } \\
\text { Country }\end{array}$ & $\begin{array}{l}\text { Number } \\
\text { of } \\
\text { patients }\end{array}$ & Type of LVAD & $\begin{array}{c}\text { Microparticles } \\
\text { assessment }\end{array}$ & $\begin{array}{l}\text { Sample } \\
\text { collection } \\
\text { period }\end{array}$ & Key results \\
\hline $\begin{array}{l}\text { Diehl et al., } \\
2010, \\
\text { Germany }\end{array}$ & 12 & $\begin{array}{l}\text { HeartMate II (6) } \\
\text { Thoratec VAD (2) } \\
\text { Ventrassist (2) } \\
\text { Circulite (1) } \\
\text { ECMO (1) }\end{array}$ & $\begin{array}{c}\text { Flow } \\
\text { cytometry }\end{array}$ & $\begin{array}{c}\text { Not } \\
\text { specified }\end{array}$ & $\begin{array}{l}\text { Microparticles levels significantly } \\
\text { higher in LVAD patients compared } \\
\text { to healthy controls. }\end{array}$ \\
\hline $\begin{array}{l}\text { Pitha et al., } \\
2012, \\
\text { Czech } \\
\text { Republic }\end{array}$ & 8 & $\begin{array}{l}\text { HeartMate II } \\
\quad \text { (axial) }\end{array}$ & ELISA & $\begin{array}{l}\text { Baseline } \\
3 \text { months }\end{array}$ & $\begin{array}{c}\text { No significant changes in } \\
\text { concentration of circulating } \\
\text { microparticles before and } 3 \text { months } \\
\text { after LVAD implant. }\end{array}$ \\
\hline $\begin{array}{l}\text { Nascimben } \\
\text { e et al., } \\
\text { 2014, USA }\end{array}$ & 20 & $\begin{array}{l}\text { HeartMate II } \\
\quad \text { (axial) }\end{array}$ & $\begin{array}{c}\text { Flow } \\
\text { cytometry }\end{array}$ & $\begin{array}{l}\text { Baseline } \\
\text { Discharge } \\
3 \text { months } \\
\text { after } \\
\text { implant }\end{array}$ & $\begin{array}{l}\text { Higher levels of phosphatidylserine } \\
\text { positive microparticles in patients } \\
\text { before LVAD implant compared to } \\
\text { healthy controls. } \\
\text { Significantly higher levels of } \\
\text { microparticles in patients who } \\
\text { developed an adverse event. }\end{array}$ \\
\hline $\begin{array}{l}\text { Ivak et al., } \\
2014, \\
\text { Czech } \\
\text { Republic }\end{array}$ & 30 & $\begin{array}{l}\text { HeartMate II } \\
\quad \text { (axial) }\end{array}$ & ELISA & $\begin{array}{l}\text { Baseline } \\
3 \text { months } \\
\text { after } \\
\text { implant }\end{array}$ & $\begin{array}{l}\text { Significant decrease in concentration } \\
\text { of circulating microparticles before } \\
\text { and } 3 \text { months after LVAD implant. }\end{array}$ \\
\hline $\begin{array}{l}\text { Sansone et } \\
\text { al., 2015, } \\
\text { Germany }\end{array}$ & 14 & $\begin{array}{c}\text { HeartWare LVAS } \\
\text { (centrifugal) }\end{array}$ & $\begin{array}{c}\text { Flow } \\
\text { cytometry }\end{array}$ & $\begin{array}{l}3 \text { months } \\
\text { after } \\
\text { implant }\end{array}$ & $\begin{array}{l}\text { Microparticles levels of both platelet } \\
\text { and endothelial origin were } \\
\text { significantly increased in LVAD } \\
\text { patients when compared to healthy } \\
\text { controls and controls with stable } \\
\text { coronary artery disease. }\end{array}$ \\
\hline
\end{tabular}

leukocyte, and endothelial activation and vascular inflammation (Diehl et al.2010). Microparticles of these origins were measured by flow cytometry in 12 patients with LVADs and compared to healthy controls. Patients with LVAD support had significant ( $p=0.002$ for platelet and $\mathrm{p}<0.001$ for leukocyte and endothelial microparticles) increased concentration of all measured microparticles, suggesting increased vascular inflammation, platelet activation, cellular apoptosis and endothelial dysfunction, which may accelerate proatherothrombotic changes in blood vessels and increase risk of thromboembolic and bleeding complications.
Importantly, the analysis used in this study implicates a role of platelet specific microparticles, which are believed to give rise to most of released tissue factor as a surrogate factor of pump thrombosis. In summary, this study underscores a need for more origin specific assays to discern vascular and endothelial related properties in contrast to systemic, e.g. pump contact surfaces - blood activation associated microparticle deviations. However, a limitation of this study was that it comprised different LVAD systems (axial, centrifugal, short-term, etc.).

$$
\text { In another study including } 20 \text { patients }
$$

(Nascimbene et al. 2014), the concentration of 
microparticles was established by flow cytometry and the concentration of aforementioned phosphatidylserine. Results showed that the concentration of microparticles was significantly higher $(\mathrm{p}<0.001)$ in patients who developed an adverse event as defined by the Interagency Registry for Mechanically Assisted Circulatory Support (INTERMACS) (Kirklin et al. 2014). In patients without adverse events, no significant change in the concentration of microparticles was observed after LVAD implantation and at 3 months following implantation. These results suggest that microparticle detection is a promising predictor of LVAD-associated adverse events.

\section{Microparticles as a marker of vascular status}

In our pilot study, we did not observe significant changes in concentration of circulating microparticles 3 months after implantation of an axial LVAD (Pitha et al. 2012). However, in our expanded study of 30 enrolled patients (Ivak et al. 2014), plasma levels of circulating microparticles were significantly decreased after 3 months following implantation $(\mathrm{p}=0.003)$. No difference was observed between patients with ischemic and non-ischemic etiology of heart failure $(p=0.53)$ or between men and women $(p=0.9)$. In both aforementioned studies, concentrations of circulating microparticles have been assessed by the ELISA method. Results of this study suggest improvement of vascular function after VAD implantation. The decrease of microparticles at 3 months after VAD implantation reflects potential improvement in vascular function. However, the results are not able to address in detail which specific biological mechanisms connected with the vascular system are involved in these processes. The ELISA assessment method is rather non-specific and cannot reliably determine cell origin of the microparticles. In addition, prediction of adverse events using microparticles was not analyzed in these studies. Another limitation could be the fact, that microparticle levels were not assessed at the time of possible adverse events, as in previously conducted study by Nascimbene et al. Observed results could be explained by a wide range of changes, including improved circulatory status and organ perfusion, improved endothelial function and/or alteration of thrombogenic factors, or combination of all these factors. This explanation is also supported by a recently published study, which reported improved microvascular circulatory parameters measured during reactive hyperemia in forearm (Sansone et al. 2015). In this study, also microparticles of different origin were assessed by flow cytometry in 14 patients with implanted centrifugal LVADs 3 months after implantation. Results showed higher concentration of blood cell- and endothelium-derived microparticles when compared to healthy controls and controls with stable coronary artery disease. Authors propose explanation, that higher concentrations of blood cell-origin microparticles are most probably the result of lower shear stress accompanied by higher/unique mechanical forces exerted on circulating blood cells. Significantly increased levels of endothelium-derived microparticles (CD31 ${ }^{+} / \mathrm{CD} 41^{-}$, $\mathrm{CD} 2 \mathrm{e}^{+}, \mathrm{CD} 144^{+}$) compared to healthy controls and patients with stable coronary artery disease may suggest possible negative impact of the generated continuous flow on endothelial function. Major limitation of this study was the absence of baseline values for longitudinal comparison. Assumingly, implantation of ventricular assist device led to an activation of endothelium cells and platelets, described as higher plasmatic levels of microparticles of these origins.

When comparing above discussed studies, not only type of used assay, but also the type of ventricular assist device might have effect on concentrations of microparticles.

To the best of our knowledge, there are no published studies, which describe more exactly the representation of specific microparticles by their origin. Therefore, it is not clear, whether status of vasculature or even prediction of clinical adverse events is associated more robustly with overall concentrations of microparticles or rather with concentrations of cellspecific microparticles.

\section{Conclusions}

Circulating microparticles play an important role in the regulation of inflammation, thrombosis, or endothelial function. Plasmatic levels of microparticles are increased in most cardiovascular diseases, probably reflecting activation or damage of circulating cells or cells of the vasculature itself. Cellular origin of circulating microparticles may predict their role and potential regulatory function in endothelial regulation, thrombus formation, and inflammatory response. Sparse data exist regarding levels and the role of circulating microparticles in patients with end-stage heart failure, and even less data are available in patients after implantation of a ventricular assist device. Recent 
developments in implantable LVADs offer possibilities for long-term use of these devices as an alternative to the heart transplant in the near future. Because most of these devices utilize the principle of continuous flow, longterm impact of this flow pattern on bloodstream and vasculature remains unclear. Several studies describe only small effect of continuous flow on end-organ function (Rogers et al. 2010, Bhimaraj et al. 2015); however, the impact of LVADs on large arteries is, according to histological findings, mainly unfavorable including decrease in the number of smooth muscle cells in tunica media, higher medial degeneration, fragmentation of elastin fibers, medial fibrosis, and even atherosclerotic changes (Westaby et al. 2007, Segura et al. 2013).

Measurement of the concentration of circulating microparticles in peripheral blood might be of significant importance in assessment of vasculature status in patients with continuous-flow LVADs. In spite of many questions regarding the routine clinical use of this methodology, such direction of research is highly promising for future management of patients with LVADs and for more detailed understanding of vascular physiology in general. On the basis of continuing intensive research and longterm observations, the clarification of the role of circulating microparticles in assessment of vascular function can be expected in the near future. In particular, the correlation of these parameters with clinical data, including major clinical adverse events, could prove useful in detection and management of adverse events in patients with LVADs.

\section{Conflict of Interest}

Dr. Netuka is a proctor and speaker for St. Jude Medical. Other authors - none declared.

\section{Acknowledgements}

This article was supported by a grant of Ministry of Health of Czech Republic, IGA MZ NT/14019-3/2013.

\section{References}

ALEMAN MM, GARDINER C, HARRISON P, WOLBERG AS: Differential contributions of monocyte- and plateletderived microparticles towards thrombin generation and fibrin formation and stability. J Thromb Haemost 9 : 2251-2261.

AMABILE N, CHENG S, RENARD JM, LARSON MG, GHORBANI A, MCCABE E, GRIFFIN G, GUERIN C, HO JE, SHAW SY, COHEN KS, VASAN RS, TEDGUI A, BOULANGER CM, WANG TJ: Association of circulating endothelial microparticles with cardiometabolic risk factors in the Framingham Heart Study. Eur Heart J 35: 2972-2979, 2014.

AMABILE N, GUIGNABERT C, MONTANI D, YEGHIAZARIANS Y, BOULANGER CM, HUMBERT M: Cellular microparticles in pathogenesis of pulmonary hypertension. Eur Respir J 42: 272-279, 2013.

AMIRAL J, SEGHATCHIAN J: The diagnostic usefulness of capture assays for measuring global/specific extracellular micro-particles in plasma. Transfus Apher Sci 53: 127-136, 2015.

BERNAL MIZRACHI L, JY W, JIMENEZ JJ, PASTOR J, MAURO LM, HORSTMAN LL, DE MARCHENA E, AHN YS: High levels of circulating endothelial microparticles in patients with acute coronary syndromes. $A m$ Heart J 145: 962-970, 2003.

BERNAL MIZRACHI L, JY W, FIERRO C, MACDONOUGH R, VELASQUES HA, PUROW J, JIMENEZ JJ, HORSTMAN LL, FERREIRA A, DE MARCHENA E, AHN YS: Endothelial microparticles correlate with high-risk angiographic lesions in acute coronary syndromes. Int J Cardiol 97: 439-446, 2004.

BHIMARAJ A, URIBE C, SUAREZ EE: Physiological impact of continuous flow on end-organ function: Clinical implications in the current ERA of left ventricular assist devices. Methodist DeBakey Cardiovasc J 11: 12-17, 2015.

BOULANGER CM, AMABILE N, TEDGUI A: Circulating microparticles: a potential prognostic marker for atherosclerotic vascular disease. Hypertension 48: 180-186, 2006.

BRETELLE F, SABATIER F, DESPREZ D, CAMOIN L, GRUNEBAUM L, COMBES V, D’ERCOLE C, DIGNATGEORGE F: Circulating microparticles: a marker of procoagulant state in normal pregnancy and pregnancy complicated by preeclampsia or intrauterine growth restriction. Thromb Haemost 89: 486-492, 2003. 
BURGER D, KWART DG, MONTEZANO AC, READ NC, KENNEDY CR, THOMPSON CS, TOUYZ RM: Microparticles induce cell cycle arrest through redox-sensitive processes in endothelial cells: implications in vascular senescence. $J$ Am Heart Assoc 1: e001842, 2012.

BURGER D, TOUYZ RM: Cellular biomarkers of endothelial health: microparticles, endothelial progenitor cells, and circulating endothelial cells. J Am Soc Hypertens 6: 85-99, 2012.

BURGER D, SCHOCK S, THOMPSON CS, MONTEZANO AC, HAKIM AM, TOUYZ RM: Microparticles: biomarkers and beyond. Clin Sci 124: 423-441, 2013.

BURNIER L, FONTANA P, KWAK BR, ANGELILLO-SCHERRER A: Cell-derived microparticles in haemostasis and vascular medicine. Thromb Haemost 101: 439-451, 2009.

BRUYNDONCKX L, HOYMANS VY, FREDERIX G, DE GUCHTENAERE A, VISSERS DK, VRINTS CJ, RAMET J, CONRAADS VM: Endothelial progenitor cells and endothelial microparticles are independent predictors of endothelial function. J Pediatr 165: 300-305, 2014.

CONNOR DE, EXNER T, MA DD, JOSEPH JE: Detection of the procoagulant activity of microparticle-associated phosphatidylserine using XACT. Blood Coagul Fibrinol 20: 558-564, 2009.

DIEHL, P, ALEKER M, HELBING T, SOSSONG V, BEYERSDORF F, OLSCHEWSKI M, BODE C, MOSER M: Enhanced microparticles in ventricular assist device patients predict platelet, leukocyte and endothelial cell activation. Interact Cardiovasc Thorac Surg 11: 133-137, 2010.

DIEHL P, ALEKER M, HELBING T, SOSSONG V, GERMANN M, SORICHTER S, BODE C, MOSER M: Increased platelet, leukocyte and endothelial microparticles predict enhanced coagulation and vascular inflammation in pulmonary hypertension. J Thromb Thrombolysis 31: 173-179, 2011.

DIGNAT-GEORGE F, BOULANGER CM: The many faces of endothelial microparticles. Arterioscler Thromb Vasc Biol 31: 27-33, 2010.

EDERHY S, DI ANGELANTONIO E, MALLAT Z, HUGEL B, JANOWER S, MEUELMAN C, BOCCARA F, FREYSSINET JM, TEDGUI A, COHEN A: Levels of circulating microparticles in nonvalvular atrial fibrillation. Am J Cardiol 100: 989-994, 2007.

FRANÇA CN, IZAR MC, AMARAL JB, TEGANI DM, FONSECA FA: Microparticles as potential biomarkers of cardiovascular disease. Arq Bras Cardiol 104: 169-174, 2015.

GONZALES-QUINTEIRO VH, SMARKUSKY LP, JIMENEZ JJ, MAURO LM, JY W, HORSTMAN LL, O'SULLIVAN MJ, AHN YS: Elevated plasma endothelial microparticles: preeclampsia versus gestational hypertension. Am J Obstet Gynecol 191: 1418-1424, 2004.

HOLMAN WL, NAFTEL DC, ECKERT CE, KORMOS RL, GOLDSTEIN DJ, KIRKLIN JK: Durability of left ventricular assist devices: Interagency registry for mechanically assisted circulatory support (INTERMACS) 2006 to 2011. J Thorac Cardiovasc Surg 146: 437-441, 2013.

HUGHES M, HAYWARD CP, WARKENTIN TE, HORSEWOOD P, CHORNEYKO KA, KELTON JG: Morphological analysis of microparticle generation in heparin-induced thrombocytopenia. Blood 96: 188-194, 2000.

IVAK P, PITHA J, WOHLFAHRT P, KRALOVA-LESNA I, STAVEK P, DORAZILOVA Z, STEPANKOVA J, MALY J, POKORNY M, NETUKA I: Endothelial dysfunction expressed as endothelial microparticles in patients with end-stage heart failure. Physiol Res 63: 369-373, 2014.

JY W, HORSTMAN LL, JIMENEZ JJ, AHN YS, BIRÓ E, NIEUWLAND R, STURK A, DIGNAT-GEORGE F, SABATIER F, CAMOIN-JAU L, SAMPOL J, HUGEL B, ZOBAIRI F, FREYSSINET JM, NOMURA S, SHET AS, KEY NS, HEBBEL RP: Measuring cell-derived microparticles. $J$ Thromb Heamost 2: 1842-1851, 2004.

KIRKLIN JK, NAFTEL DC, PAGANI FD, KORMOS RL, STEVENSON LW, BLUME ED, MILLER MA, TIMOTHY BALDWIN J, YOUNG JB: Sixth INTERMACS annual report: A 10,000-patient database. $J$ Heart Lung Transplant 33: 555-564, 2014.

KIRKLIN JK, NAFTEL DC, KORMOS RL, STEVENSON LW, PAGANI FD, MILLER MA, TIMOTHY BALDWIN J, YOUNG JB: Fifth INTERMACS annual report: Risk factor analysis from more than 6,000 mechanical circulatory support patients. J Heart Lung Transplant 32: 141-156, 2013. 
KIRKLIN JK, NAFTEL DC, PAGANI FD, KORMOS RL, STEVENSON LW, MILLER M, YOUNG JB: Long-term mechanical circulatory support (destination therapy): On track to compete with heart transplantation? J Thorac Cardiovasc Surg 144: 584-603, 2012.

LACROIX R, ROBERT S, PONCELET P, DIGNAT-GEORGE F: Overcoming limitations of microparticle measurement by flow cytometry. Semin Thromb Hemost 36: 807-818, 2010.

MCGINN C, MACDONNELL BF, SHAN CX, WALLACE R, CUMMINS PM, MURPHY RP: Microparticles: A pivotal nexus in vascular homeostasis and disease. Curr Clin Pharmacol 11: 28-42, 2016.

NASCIMBENE A, HERNANDEZ R, GEORGE JK, PARKER A, BERGERON AL, PRADHAN S, VIJAYAN KV, CIVITELlO A, SIMPSON L, NAWROT M, LEE VV, MALLIDI HR, DELGADO RM, DONG JF, FRAZIER OH: Association between cell-derived microparticles and adverse events in patients with nonpulsatile left ventricular assist devices. J Heart Lung Transplant 33: 470-477, 2014.

NOMURA S, TANDON NN, NAKAMURA T, CONE J, FUKUHARA S, KAMABAYASHI J: High-shear-stressinduced activation of platelets and microparticles enhances expression of cell adhesion molecules in THP-1 and endothelial cells. Atherosclerosis 158: 277-287, 2001.

OWEN B, XUE A, HEIT J, OWEN W: Procoagulant activity, but not number, of microparticles increases with age and in individuals after a single venous thromboembolism. Thromb Res 127: 39-46, 2011.

PICCIN A, MURPHY WG, SMITH OP: Circulating microparticles: pathophysiology and clinical implications. Blood Rev 21: 157-171, 2007.

PITHA J, DORAZILOVA Z, MELENOVSKY V, KRALOVA-LESNA I, STAVEK P, STEPANKOVA J, URBAN M, MALY J, NETUKA I: The impact of ventricle assist device on circulating endothelial microparticles - pilot study. Neuro Endocrinol Lett 33: 68-72, 2012.

PRESTON RA, JY W, JIMENEZ JJ, MAURO LM, HORSTMAN LL, VALLE M, AIME G, AHN YS: Effects of severe hypertension on endothelial and platelet microparticles. Hypertension 41: 211-217, 2003.

ROGERS JG, AARONSON KD, BOYLE AJ, RUSSEL SD, MILANO CA, PAGANI FD, EDWARDS BS, PARK S, JOHN R, CONTE JV, FARRAR DJ, SLAUGHTER MS: Continuous flow left ventricular assist device improves functional capacity and quality of life of advanced heart failure patients. $J$ Am Coll Cardiol 55: 1826-1834, 2010.

RUBIN O, CANELLINI G, DELOBEL J, LION N, TISSOT JD: Red blood cell microparticles: Clinical relevance. Transfus Med Hemoter 39: 342-347, 2012.

SABATIER F, DARMON P, HUGEL B, COMBES V, SANMARCO M, VELUT JG, ARNOUX D, CHARPIOT P, FREYSSINET JM, OLIVER C, SAMPOL J, DIGNAT-GEORGE F: Type 1 and type 2 diabetic patients display different patterns of cellular microparticles. Diabetes 51: 2840-2845, 2002.

SAPET C, SIMONCINI S, LORIOD B, PUTHIER B, SAMPOL J, NGUYEN C, DIGNAT-GEORGE F, ANFOSSO F: Thrombin-induced endothelial microparticle generation: identification of a novel pathway involving ROCK-II activation by caspase-2. Blood 108: 1868-1876.

SCHIRO A, WILKINSON FL, WESTON R, SMYTH JV, SERRACINO-INGLOTT F, ALEXANDER MY: Endothelial microparticles as conveyors of information in atherosclerotic disease. Atherosclerosis 234: 295-302, 2014.

SANSONE R, STANSKE B, KEYMEL S, SCHULER D, HORN P, SAEED D, BOEKEN U, WESTENFELD R, LICHTENBERG A, KELM M, HEISS C: Macrovascular and microvascular function after implantation of left ventricular assist devices in end-stage heart failure: Role of microparticles. J Heart Lung Transplant 34: 921-932, 2015.

SEGURA AM, GREGORIC I, RADOVANCEVIC R, DEMIROZU ZT, BUJA LM, FRAZIER OH: Morphologic changes in the aortic wall media after support with a continuous-flow left ventricular assist device. J Heart Lung Transplant 32: 1096-1100, 2013.

SHAH KB, KONTOS MC: Microparticles and left ventricular assist device complications: a causal association? J Heart Lung Transplant 33: 468-469, 2014. 
SINGH N, VAN CRAEYVELD E, TJWA M, CIARKA A, EMMERECHTS J, DROOGNE W, GORDTS SC, CARLIER V, JACOBS F, FIEUWS S, VANHAECKE J, VAN CLEEMPUT J, DE GEEST B: Circulating apoptotic endothelial cells and apoptotic endothelial microparticles independently predict the presence of cardiac allograft vasculopathy. $J$ Am Coll Cardiol 60: 324-331, 2012.

SINAURIDZE EI, KIREEV DA, POPENKO NY, PICHUGIN AV, PANTELEEV MA, KRYMSKAYA OV, ATAULLAKHANOV FI: Platelet microparticle membranes have 50- to 100-fold higher specific procoagulant activity than activated platelets. Thromb Haemost 97: 425-434, 2007.

TRAMONTANO AF, LYUBAROVA R, TSIAKOS J, PALAIA T, DELEON JR, RAGOLIA L: Circulating endothelial microparticles in diabetes mellitus. Mediators Inflam 2010: 250476, 2010.

VAN WIJK MJ, NIEUWLAND R, BOER K, VAN DEN POST JA, VAN BAVEL E, STURK A: Microparticle subpopulations are increased in preeclampsia: possible involvement in vascular dysfunction? $\mathrm{J} \mathrm{Am} \mathrm{Obstet}$ Gynecol 187: 450-456, 2002.

VAN WIJK MJ, VAN BAVEL E, STURK A, NIEUWLAND R: Microparticles in cardiovascular diseases. Cardiovasc Res 59: 277-287, 2003.

VIERA AJ, MOOBERRY M, KEY NS: Microparticles in cardiovascular disease pathophysiology and outcomes. $J \mathrm{Am}$ Soc Hypertens 6: 243-252, 2012.

WARKENTIN TE, HAYWARD CPM, BOSHKOV LK, SANTOS AV, SHEPPARD JA, BODE AP, KELTON JG: Sera from patients with heparin-induced thrombocytopenia generate platelet-derived microparticles with procoagulant activity: An explanation for the thrombotic complications of heparin-induced thrombocytopenia. Blood 84: 3691-3699, 1994.

WESTABY S, BERTONI GB, CLELLAND C, NISHINAKA T, FRAZIER OH: Circulatory support with attenuated pulse pressure alters human aortic wall morphology. J Thorac Cardiovasc Surg 133: 575-576, 2007.

WILLIAMS JB, JAUCH EC, LINDSELL CJ, CAMPOS B: Endothelial microparticle levels are similar in acute ischemic stroke and stroke mimics due to activation and not apoptosis/necrosis. Acad Emerg Med 14: 685-690, 2007.

ZAFRANI L, INCE C, YUEN PS: Microparticles during sepsis: target, canary or cure? Intensive Care Med 39: 1854-1856, 2013.

ZHANG Y, MENG H, MA R, HE Z, WU X, CAO M, YAO Z, ZHAO L, LI T, DENG R, DONG Z, TIAN Y, BI Y, KOU J, THATTLE HS, ZHOU J, SHI J: Circulating microparticles, blood cells, and endothelium induce procoagulant activity in sepsis through phosphatidylserine exposure. Shock 45: 299-307, 2016.

ZHOU J, SHI J, HOU J, CAO F, ZHANG Y, RASMUSSEN JT, HEEGAARD CW, GILBERT GE: Phosphatidylserine exposure and procoagulant activity in acute promyelocytic leukemia. $J$ Thromb Haemost 8: 773-782, 2010. 